\title{
Forty years of real-estate bubbles in the US and the macroeconomy: a Keynesian perspective*
}

\author{
Herbert Walther** \\ Vienna University of Economics and Business, Austria
}

This paper presents a dynamic, non-linear, stock-flow consistent aggregate Keynesian model with a banking sector, a household sector, a government sector, and a real-estate sector, to study the interactions between booms and busts in the real-estate sector and the macroeconomy. Using this model we try to simulate some 'stylized facts' about the US economy observable during the last four decades. It is argued that for various reasons house-price volatility in the US has increased since the 1980s: house prices seem to have followed a 'cobweb' pattern of accelerating instability, leading to the climax of the financial crises in 2007/2008. A new run-up of house prices has already started, pointing towards a looming bubble ahead. The US economy seems to have become addicted to asset-price bubbles as the driving force of the business cycle. It is argued that various institutional changes, which can be linked to the dominant economic ideology, are responsible for these developments.

Keywords: financial instability, real-estate price bubbles, business cycles

JEL codes: $E 12, E 32, E 34, E 52, E 58, E 62$

\section{INTRODUCTION}

This paper argues that - since the early 1980s - asset-price 'bubbles' and 'slumps,' primarily but not exclusively in the real-estate market, became the driving force of the business cycle in the US. Even now, at the time of this writing (2019), the fragile boom in the US economy (accompanied by rapidly increasing house prices and the pro-cyclical fiscal and monetary policy of the Trump administration) is just another hint that the US economy has become addicted to a pattern of credit cycles, dominated by unsustainable consumption booms during the upswing based on illusionary 'wealth effects' and followed by a painful 'deleveraging' process in the slump.

In the post-war era different types of business cycles can be distinguished: In the 1950s and early 1960s, 'growth cycles' of the multiplier-accelerator type (à la Samuelson 1939; Hicks 1950), mainly triggered by real investment, dominated the picture. As the economy approached the full-employment barrier in the early 1970s, the revival of orthodox doctrines legitimated the use of unemployment as a 'disciplinary' force to restore the conditions for profitable, non-inflationary capital accumulation - a remarkable validation of

* Dedicated to the memory of my revered teacher and dear friend Kazimierz Laski.

** Email: herbert.walther@wu.ac.at.

Received 4 January 2019, accepted 8 August 2019 
Kalecki's (1943) visionary prophecies. ${ }^{1}$ 'Structural' reforms of allegedly 'rigid' labor markets blamed for the persistence of high unemployment, the globalization of trade and the liberalization of capital markets greatly diminished the power of organized labor. Increasing inequalities of income and wealth, together with the ongoing 'financialization' process (via privatization of public assets and the rising importance of investment and pension funds), laid the seed for the evolution of the 'bubble economy.'

Far from being a singular historical accident, the bursting of the house-price bubble in 2008 seems to be just a particular climax in a series of asset-price booms and busts since the early 1980s. This process started with a first flash of financial instability in the early 1980s, as the saving and loan crisis broke out in the aftermath of a mortgage crisis - caused by the interaction of the Volcker interest-rate shock and financial deregulation. We argue that each price bubble sows the seed for the next one, primarily because monetary, fiscal, and regulatory policies do not react adequately, but also because credit cycles become globally 'infectious' via 'carry trades' and 'derived' speculative activities. ${ }^{2}$

In the following analysis, we will focus on real-estate cycles: The mainstream literature on housing is treating the events of 2007/2008 as a very special episode, a 'singularity' which happens at best once in a century. The majority of these papers analyse the housing market within a general equilibrium framework (an overview of this literature is given by Piazzesi/ Schneider 2016). In such a framework, it is extremely challenging to incorporate realistic features like endogenous credit constraints, illiquidity, transaction costs, and balance-sheet effects - the fundamental mechanisms triggering a credit crisis: Garriga/Hedlund 2017 show that within a general equilibrium model the reactions to an economic shock get intensified by such 'imperfections. ${ }^{3}$ From a post-Keynesian perspective, however, the fundamental uncertainty of the future, herd behavior, limited rationality of agents, endogenous money, and endogenous risk attitudes ('irrational exuberance') are necessary ingredients of any attempt to understand the dynamics of credit cycles, of 'panics and manias' in financial markets (Mackay 1841; Kindleberger 1978) - aspects of reality which are completely at odds with the axiomatic basis of general equilibrium theory.

While price bubbles can be observed in a broad variety of asset categories, ${ }^{4}$ in the realestate market they are capable of producing particularly damaging macroeconomic repercussions. From the viewpoint of orthodox economics, however, seemingly 'irrational' price bubbles cannot be easily explained. 'Rational' speculators with a long-term view could make a profit by wiping out 'irrational' price hikes and slumps not related to fundamental

1. Kaleki (1943: 329) argued that full employment as a policy goal will be opposed by industrial leaders, because "the workers would "get out of hand" and the "captains of industry" would be anxious to "teach them a lesson".'

2. For example, the 'liquidity trap' in Japan in the early 1990s and the resulting interest differential relative to the US created opportunities for 'carry trades' fueling the asset-price boom in the US during the Clinton area (see ECB 2010).

3. The difficulty of integrating 'imperfections' into a general equilibrium framework becomes obvious from Garriga/Hedlund (2017: 23): 'An emerging but extensive literature documents two additional economic disturbances during the Great Recession: a rise in uncertainty from higher downside labor market risk and a tightening of minimum downpayment requirements. To capture these features in the model, a left tail labor shock is constructed to replicate the gradual decline in labor hours from 2007 to 2010 , and the minimum downpayment constraint increases to $10 \%$ to capture the tightening of credit.' In a Keynesian world neither the 'left tail labor shock' nor the 'tightening of credit' are 'additional disturbances,' but a natural endogenous part of the boom and bust cycle.

4. There are some signs that a credit cycle of a similar type, based on 'sophisticated' financing methods common during the house-price cycle, is evolving in the field of corporate debt (see William D. Cohan, The New York Times, 9 August 2018). 
factors enshrined in the laws of demand and supply (for example, demographic changes, changing preferences, productivity shocks, etc.). Consequently, even in the aftermath of the Great Recession of 2008, defenders of the 'efficient market hypothesis' denied that price 'bubbles' existed or could ever exist:' In his Nobel Lecture, Eugene Fama defines a bubble as an 'irrational strong price increase that implies a predictable strong decline' (Fama 2014: 1475). Fama's 'trick' is to define 'predictability' in an extremely narrow sense - suggesting that even the timing of turning points must be predictable within narrow bounds of uncertainty as an identifying condition for the existence of a 'bubble.' Obviously, if this criterion were valid, anyone could make an easy profit by speculating against such 'bubbles.'

Given the complex, sometimes chaotic (economically and politically interacting) reality, one has to define 'predictability' in a much weaker sense, however. Reasonable (that is, not 'naive') observers of market trends might fully (and correctly) agree that a price bubble is developing in front of their eyes, but they will rarely agree on how long this process of 'over- or undershooting' of prices might go on: several years from now, or will it stop tomorrow? Under such circumstances even 'rational' actors, who may be (over-?)confident to have some competitive advantage vis-à-vis 'naive' investors, might speculate to 'ride' a price bubble temporarily, thereby destabilizing the market further. ${ }^{6}$

Summarizing the available empirical evidence, Piazzesi/Schneider (2016: 4) argue: 'Rational expectations models to date cannot account for houseprice volatility - they inevitably run into 'volatility puzzles' for housing much like for other assets.' The background for the latter statement can be seen in Figure 1, which illustrates the systematic pattern of escalating cyclical deviations of home prices since the early 1980s. Actually, as one can see, the next real-estate price bubble is appearing on the stage already.

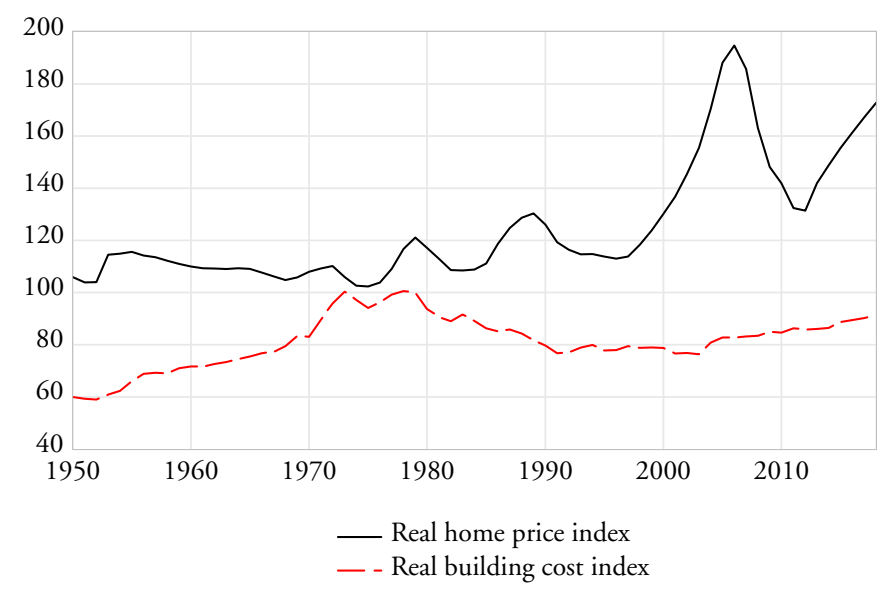

Source: Robert Shiller homepage.

Figure 1 Real home price index and real building cost index

5. See, for example, Eugene Fama's interview in The New Yorker (13 January 2010).

6. See also DeLong et al. (1990) on the question of 'rational' destabilizing speculation and Scheinkman/Wei (2003) for a behavioral approach taking into account 'overconfidence' as a possible cause for price bubbles. See also Shiller (2000) for a behavioral view of 'irrational exuberance' and the seminal article by Blanchard (1979). 
Today it is common knowledge that in the run-up of house-prices between 2000 and 2007 dubious 'financial innovations' opened the door for the widespread moral hazard of banks and rating agencies. Securitization and credit default swaps prepared the ground for balance-sheet manipulations of banks and pure fraud. 'NINA' (no interest, no amortization) credits and the insurance schemes offered by Fannie Mae and Freddy Mac created a climate in which mortgage credits became far too easily available even for households without sufficient collateral. Due to their complexity, the celebrated financial innovations delivered a convenient veil for the growing systemic risk of financial markets: to maximize the return on equity, multi-layered leverage effects had been constructed (see also Bhaduri 2011).

Paradoxically, as this process reached its climax during the period 2003-2007, mainstream economists and central bankers argued that the US financial system had become much more resilient against external shocks due to 'financial sophistication.' Greenspan (2003): 'The use of a growing array of derivatives and the related application of moresophisticated methods for measuring and managing risk are key factors underpinning the enhanced resilience of our largest financial intermediaries.' The theory of 'capital market efficiency' - which became the core of modern capital market theory during the 1990s delivered the intellectual justification for this hubris.

Shockingly, quite to the contrary, as the financial system became more and more integrated and connected, the destructive potential of bursting asset-price bubbles increased considerably. Few economists (for example, Godley 2001; 2002) were willing to acknowledge the threat of the accumulating imbalances due to rapidly falling savings rates and the rising indebtedness rate of households. Paradoxically, Godley's repeated warnings of a looming recession (jeopardizing the chances of George W. Bush of getting re-elected in 2004) had the disastrous effect - in hindsight - of motivating the Federal Reserve (Fed) to lower the fund rate from 3.9 percent in 2001 to 1.1 percent in 2003 the year when the house-price bubble started to get fully out of control.

\section{A DYNAMIC MODEL OF REAL-ESTATE BUBBLES}

Below we will explore, within a non-linear, stock-flow consistent Keynesian model, escalating price and credit cycles in a housing market. We will try to mimic some 'stylized' facts of the US economy with our dynamic model (using Maple 15). We will try to demonstrate that critical parameter shifts generating higher instability can be linked to the revival of anti-Keynesian economic policy and ideology. We will compare different monetary and fiscal rules within our framework and we will show the disastrous consequences of focusing on stabilizing the government debt-to-GDP ratio, that is, following a simple 'Maastricht rule,' or the rules of the 'Swabian housewife.'

We will also check whether a target line for private credit growth (compatible with a certain rate of nominal income growth) should be integrated into a modified monetary policy rule. It might be plausible that the weight given to this target depends upon the relative volatility of asset prices. The higher the volatility is, the more important might be the credit growth target. The importance of controlling the credit sphere is also underlined in some

7. The German chancellor Angela Merkel in 2008 on the causes of the financial crisis: 'One should have asked the Swabian housewife - she would have told us a worldly wisdom: you cannot live forever beyond your means' (cited from URL: https://www.faz.net/aktuell/wirtschaft/schuldendie-schwaebische-hausfrau-1979097.html). 
recent post-Keynesian papers by Werner (2015) and Dejuán/Dejuán-Bitriá (2018). Contrary to mainstream economics, post-Keynesian economics always had a much more critical view of the role of credit and financial factors in booms and busts (for example, Minsky 1992; Palley 1994; 2011; Godley/Lavoie 2006; Koo 2011; Hein 2012; Admati/Hellwig 2013; Ryoo 2013).

The presented model is similar in spirit to Bhaduri et al. (2006), who focus on the interaction between the 'real' and the 'virtual' economy via 'illusionary' wealth effects. It focuses on the dynamic interaction between 'cobweb-type' cycles in the real-estate sector and the macro level of the economy. The model extends the Bhaduri et al. (2006) perspective of the interaction between 'virtual wealth' and the real economy by integrating the balance-sheet behavior of the banking sector and by comparing different policy rules with regard to their stability properties. The main chain of interaction runs via capital gains and losses of home owners, endogenous income and credit constraints, and balance-sheet effects in the banking sector. 'Debtor' households and 'creditor' households (the shareholders of the banking sector) are explicitly distinguished.

\subsection{The accounting framework}

We distinguish a banking sector, a sector of debtor households, a sector of creditor households (or 'rentiers') and a government sector. The central bank is assumed to be part of the government sector. Let us first take a look at the basic accounting relationships.

The consolidated banking sector's asset and liability balance (Table 1) has to take into account the legal minimum reserves of 'central-bank money' as a percentage of demand deposits. We assume a cashless economy (implying monetary base = central-bank credits). As banks have no incentives whatsoever to hold excess reserves above the legal minimum, the sum of demand deposits is always equal to the sum of mortgage and government bonds minus equity. For the sake of simplicity, government bonds are held by the banking sector only. For equity to exist at all, in the past some demand deposits must have been swapped to shares. The shareholders of banks will be called 'rentiers' or 'creditor households.' The banking sector borrows the minimum reserves from the central bank at the fund rate fixed by the central bank and adjusts those reserves in accordance with credit creation or destruction. Banks are offering payment services, but do not pay monetary interest on demand deposits.

In addition (and very importantly), banks are obligated to adjust equity in accordance with legal requirements: they must hold a certain minimum ratio of equity relative to 'risky' assets (= mortgage credits in our model). Equity gets adjusted via retained profits (Table 2). Capital gains and losses are included in the tax base for corporate taxes.

The 'virtual' income balance of debtor households (which includes the wages of employees of the banking sector, and capital gains and losses on the left-hand side) is given by Table 3. Interest payments, 'maintenance expenditures,' and property taxes are deductible from the income-tax base.

\section{Table 1 The banking sector's asset and liability balance}

\begin{tabular}{ll}
\hline Assets & Liabilities \\
\hline Minimum reserves & Central-bank credits \\
Mortgage bonds & Demand deposits \\
Government bonds & Equity \\
\hline
\end{tabular}


Table 2 The banking sector's income balance

\begin{tabular}{ll}
\hline Resources & Uses \\
\hline Interest received from mortgage credits & Interest paid to the central bank \\
Interest received from government bonds & Wages paid to employees \\
Capital gains or losses & Corporate taxes \\
& Retained profits \\
& Distributed profits \\
\hline
\end{tabular}

Table 3 The debtor households' income balance

\begin{tabular}{ll}
\hline Resources & Uses \\
\hline Gross value added & Interest payments on mortgage credits \\
Wages of employees in the banking sector & Maintenance expenditures \\
Capital gains or losses & Property taxes \\
& Income taxes \\
& Consumption of debtor households \\
& Saving \\
\hline
\end{tabular}

Table 4 The creditor households' income balance

\begin{tabular}{ll}
\hline Resources & Uses \\
\hline Distributed profits & Income taxes \\
& Consumption of rentier households \\
& Saving \\
\hline
\end{tabular}

Table 5 The government's income balance

\begin{tabular}{ll}
\hline Resources & Uses \\
\hline Interest received (via central bank) & Government consumption \\
Income taxes & Interest paid on government bonds \\
Property taxes & Budget surplus/deficit \\
Corporate taxes & \\
\hline
\end{tabular}

Table 6 Uses of goods and services

\begin{tabular}{ll}
\hline Resources & Uses \\
\hline GDP & Consumption of debtor households \\
& Consumption of creditor households \\
& Government consumption \\
& Gross investment \\
\hline
\end{tabular}

The consolidated income balance of the 'rentier' households is given by Table 4 . The system gets closed by the income balance of the government sector (Table 5) and the uses of goods and services (Table 6). 


\section{THE MODEL}

\subsection{The balance-sheet framework in analytical terms}

Let us start with the description of the balance-sheet framework in analytical terms:

$$
\begin{aligned}
B(t) & =p(t) q(t) \\
B^{\prime}(t) & =p^{\prime}(t) q(t)+p(t) q^{\prime}(t)=V(t)+W(t) \\
G(t) & =V(t)>0 \\
L(t) & =V(t) \leq 0 \\
y_{d}(t) & =\left(1-\theta_{w}\right)\left(y(t)+T-\left(n(t)+\theta_{p}+\delta\right) B(t)\right)+G(t)+\omega L(t) \\
Z(t) & =n(t)(B(t)+\Omega F(t))-d(t)(B(t)+F(t)-R(t))+(1-\omega) L(t)-R^{\prime}(t) \\
y_{c}(t) & =\left(1-\theta_{w}\right)\left(1-\theta_{c}\right)(Z(t)-T) \\
\Phi(t) & =\frac{y_{c}(t)}{R(t)} \\
m(t) & =\theta_{w}\left(y(t)-\left(n(t)+\theta_{p}\right) B(t)+T\right)+\theta_{p} B(t) \\
& +\left(\theta_{c}+\theta_{w}\left(1-\theta_{c}\right)\right)(Z(t)-T)-n(t) \Omega F(t) \\
E(t) & =c_{d}(t)+c_{c}(t)+\delta q(t)+q^{\prime}(t)+g(t) .
\end{aligned}
$$

In equation (1), the variable $B(t)$ designates the outstanding stock of mortgage credits, $p(t)$ the price level of houses, and $q(t)$ the current stock of houses. For the sake of simplicity, we assume that the value of outstanding mortgage credits, $B(t)$, will (and must) be always covered by the value of the underlying collateral, $p(t) q(t)$. This will be the case if $V(t)=p^{\prime}(t) q(t)$ gets absorbed into the income balances either of debtor (5) or creditor households (7) and if $W(t)=p(t) q^{\prime}(t)$ induces an equivalent and instantaneous adjustment of mortgage debt. Capital gains, $G(t)$, and capital losses, $L(t)$, are separately defined in (3) and (4), because the distribution of capital gains and losses between debtor households and creditors might differ for capital gains and losses:

1. We assume that $G(t)$ gets fully allocated to debtor households. Even if some households cannot bear the interest burden during an ongoing boom, the worst case for them is to sell their home, to liquidate the debt and to realize the capital gain (this scenario had been a 'selling point' for the infamous NINA credits in the run-up to the financial crisis).

2. $L(t)$ on the other hand will be allocated mainly to creditors according to $(1-\omega) L(t)$ in (6). As some debtors will be able to shoulder the burden by liquidating the debt 'overhang,' $0 \leq \omega \leq 1$ is possible. Lower $\omega$ makes the distribution of capital losses more favorable for debtor households. Capital gains, $G(t)$, motivate debtor households to draw additional mortgage credits for consumption purposes. Neither $G(t)$ nor $L(t)$ enter the income-tax base of households, but are subject to the corporate tax. 
'Depreciation' is a random event - destroying houses with probability $\delta$. Debtor households pay a credit insurance premium, $\delta p(t) q(t)$, to guarantee that under such circumstances the debt gets liquidated and the houses could (but must not) be reconstructed. If $p(t)<1$, some houses will not be rebuilt, as the owners might turn to the secondary market. The supply of houses decreases $\left(q^{\prime}(t)<0\right)$, and nominal net investment $W(t)=p(t) q^{\prime}(t)$ will be negative. Due to the credit insurance, deposits and mortgage credits will decrease by the same amount, leaving the equity of banks unchanged. ${ }^{8}$

The 'virtual' disposable income of debtor households, $y_{d}(t)$ is defined according to the right-hand side of (5): $y(t)$ is the gross value added, $T$ is the gross income of employees in the banking sector (assumed to be exogenously given), $n(t)$ is the nominal mortgage interest rate, $\theta_{p}$ is the property tax rate (calculated on the basis of the mark-to-market value of homes), and $\theta_{w}$ is the income-tax rate. Interest payments, property taxes, and insurance costs are deductible from the income-tax base. The interest rate for mortgage credits is continuously variable and of infinite maturity.

$Z(t)$ in equation (6) defines the gross value added of the banking sector (net of capital gains/losses and retained profits, $R^{\prime}(t)$, which are by definition equal to the change of equity). Banks receive all interest payments for mortgage credits and government debt. The interest on government debt is assumed to be lower than the interest on risky mortgage credits $(0<\Omega<1)$. Interest paid by banks to the central bank is the product of the fund rate, $d(t)$, and the stock of central-bank credits. The obligatory ratio of minimum reserves to deposits is equal to $l$, and demand deposits are by definition equal to $F(t)+B(t)-R(t)$.

Taxable gross profits in the banking sector are given by $Z(t)$ minus gross income of employees in the banking sector, $T$, which is assumed to be exogenously given. Profits are taxed at the corporate tax rate, $0 \leq \theta_{c} \leq 1$. The residual gets distributed to rentier households, where it gets taxed at the income tax rate, $0 \leq \theta_{w} \leq 1$. The net income of rentiers is $y_{c}(t)$. The net profit rate on equity in the banking sector, $\Phi(t)$, is defined according to (8) as the ratio of net disposable creditor income, $y_{c}(t)$, to equity, $R(t)$. Equation (9) defines the disposable income of the government, $m(t)$.

Finally, effective aggregate demand, $E(t)$, is given by (10) as the sum of consumption expenditures of debtor and creditor households, real investment in housing $\left(=\delta q(t)+q^{\prime}(t)\right)$, plus government expenditures for goods and services $(=g(t))$.

\subsection{The behavioral equations of the model}

\subsubsection{The real-estate market}

Equation (11) postulates that the housing supply, $q(t)$, changes in proportion to the deviations of the expected mark-to-market price level of houses from building costs (normalized at the level of one). As the building process is time consuming (which we do not model explicitly), we postulate that construction firms are calculating with expected price levels by inflating (deflating) current prices with the current rate of house-price changes. Equation (12) describes the price adjustment in the housing market: house prices rise in

8. This means that our balance sheets should be expanded by the income balance of a non-profit insurance sector, which gets resources $\delta p(t) q(t)$ and spends the money on reconstruction or debt liquidation. 
proportion to the relative difference between the total demand for houses, $x(t)$, and the total supply of houses, $q(t)$.

$$
\begin{aligned}
\frac{q^{\prime}(t)}{q(t)} & =\alpha\left(p(t)\left(1+\frac{p^{\prime}(t)}{p(t)}\right)-1\right) & & \alpha>0 \\
\frac{p^{\prime}(t)}{p(t)} & =\beta\left[\frac{x(t)-q(t)}{q(t)}\right] & & \beta>0 \\
\hat{x}(t) & =\frac{\hat{B}(t)}{p(t)}\left[\frac{\Phi(t)}{\Phi_{0}}\right]^{\zeta} & & \varsigma \geq 0 \\
\hat{B}(t) & =\nu \frac{y_{d}(t)}{\left(1-\theta_{w}\right)\left(n(t)+\theta_{p}+\delta\right)} & & \nu>0 \\
\frac{x^{\prime}(t)}{x(t)} & =\tau\left[\frac{\hat{x}(t)-q(t)}{q(t)}\right] & & \tau>0
\end{aligned}
$$

Equation (13) postulates that the 'feasible' level of the demand for housing, $\hat{x}(t)$, depends on the 'feasible' level of household debt, $\hat{B}(t)$, which is explicitly specified in equation (14), and on the rate of return on equity, $\Phi(t)$, relative to its 'normal' value, $\Phi_{0}$.

By judging potential debtors, banks calculate $\hat{B}(t)$ by asking households whether they can afford the financial burden of buying a house. The sum of interest payments, property taxes, and 'insurance' costs should not surpass a certain ratio relative to the virtual disposable income of debtor households. As a rule of thumb, as a rough 'guideline' only, the 'feasible debt' is fixed as the ratio $v$ to this virtual disposable income (14). The second factor, the influence of the relative return on equity via elasticity, $\zeta>0$, represents the 'Minsky' hypothesis: credit standards get more (less) 'relaxed,' when profitability is higher/lower than normal, as bankers are willing to take more (less) risks, when profits are higher (lower) than usual. The fact that the credit supply of banks reacts endogenously to changes of $y_{d}(t)$ and $\Phi(t)$ is the main trigger of financial instability in our model. ${ }^{9}$

Equation (15) defines the adjustment of the actual demand for houses, assumed to be proportional to the relative difference between the 'feasible' and the 'actual' level of houses in the economy. During a crisis, $\hat{x}(t)<q(t)$ will be the case. Under such circumstances the stock of outstanding debt, $B(t)=p(t) q(t)$, does not fulfill the 'usual' credit standards any more. Some households will not be able to fulfill their financial obligations any longer, implying foreclosures and capital losses for banks and/or households. Furthermore, as the profit rate falls below the 'normal' level, bankers might become more risk-averse and less willing to offer credits.

\subsubsection{The banking sector}

Banks are promoting the demand for credits during the boom and are enforcing repayment and/or liquidation of debt during the recession in line with the changing mark-to-market

9. Geneakopolous (2010) has demonstrated that the simple model of credit demand and supply, where the interest rate is clearing the market, is unable to explain many aspects of credit markets, as rationing based on creditworthiness and endogenously determined values of the collateral are important. 
value of houses. As the volume of mortgage debt changes, the level of equity, $R(t)$, gets adjusted according to (16). The desired ratio of equity to mortgage credits, $\chi$, will always be higher than the legal minimum due to risk-aversion.

One might argue that $\chi$ (and/or the speed of adjustment, $\eta$ ) might vary over time: as prudent managers with a long-term view try to stabilize dividend payments (and attempt to minimize tax payments) over time, $\chi$ (and $\eta$ ) rise in the boom and fall in the slump. On the other hand, over-confident and greedy managers might even reduce $\chi$ (and $\eta$ ) during the boom to maximize dividend payments to shareholders. As the crisis starts, panic and a shift towards risk-aversion will evolve, and $\chi$ (and maybe also $\eta$ ) might rise again. Obviously, such herding behavior could work as a powerful destabilizing force.

History seems to demonstrate that, in line with the 'shareholder value' philosophy, the incentive for financial managers to perform 'above average' might have become stronger since the early 1980s. Furthermore, competition from the shadow banks is acting as a pressure to decrease the desired capital ratio towards the legal minimum boundary, which makes the system less resilient (as will be shown below).

$$
\frac{R^{\prime}(t)}{R(t)}=\eta\left[\frac{\chi B(t)-R(t)}{R(t)}\right] \quad \eta>0
$$

\subsubsection{The household sector}

Equations (17) and (18) define the consumption functions of debtor and creditor households respectively. The second term on the right-hand side makes sure that households must obey their budget constraints in the long run. Typically, we expect $b_{c}<b_{d}$ and $\mu_{d}<\mu_{c}$, as creditor households will be richer on average than debtor households, which implies that they have more 'leeway' to deviate from short-run budget constraints (with the rise of 'pension fund capitalism,' these differences might have become somewhat less relevant).

In our 'stationary' economy, saving or dissaving is only a short-run temporary phenomenon, changing the liquidity position of households vis-à-vis other sectors. Debtor households are not allowed to repay mortgages when they 'save,' nor do they get additional credits during periods of 'dissaving.'

$$
\begin{gathered}
\frac{c_{d}{ }^{\prime}(t)}{c_{d}(t)}=b_{d} \frac{y_{d}{ }^{\prime}(t)}{y_{d}(t)}-\mu_{d}\left(\frac{c_{d}(t)}{y_{d}(t)}-1\right) \\
\frac{c_{c}{ }^{\prime}(t)}{c_{c}(t)}=b_{c} \frac{y_{c}{ }^{\prime}(t)}{y_{c}(t)}-\mu_{c}\left(\frac{c_{c}(t)}{y_{c}(t)}-1\right)
\end{gathered}
$$

Finally, the gradual adjustment of production to aggregate effective demand (10) is postulated to behave according to equation (19).

$$
y^{\prime}(t)=E(t)-y(t)
$$

\subsubsection{The fiscal policy rule}

Equation (20) describes the fiscal policy rule of 'the' government.

$$
\frac{g^{\prime}(t)}{g(t)}=\varphi \frac{m^{\prime}(t)}{m(t)}-f\left(j(y(t)-1)+(1-j)\left(\frac{g(t)}{m(t)}-1\right)\right)
$$


We assume that (local and state) government spending reacts endogenously and pro-cyclically to changes in their disposable income $(0<\varphi<1)$, while the central government reacts in a Keynesian way to the GDP gap, as $f>0$. This reaction might be purely endogenous via unemployment benefits, etc., but could also be the result of discretionary policy. The parameter $j(0 \leq j \leq 1)$ determines the comparative weights of 'Keynesian' versus 'orthodox' balanced budget rules. For $j=0$, the famous rule of the 'Swabian housewife' results. This rule simply imitates the consumption behavior of private households. Instead of stabilizing the net deficit, an orthodox government might also try to stabilize the debt-to-GDP ratio à la Maastricht.

$$
\frac{g^{\prime}(t)}{g(t)}=\varphi \frac{m^{\prime}(t)}{m(t)}-f\left(j(y(t)-1)+(1-j)\left(\frac{F(t)}{y(t)}-\varepsilon\right)\right)
$$

Alternatively, government debt relative to potential GDP might be stabilized.

\subsubsection{The monetary policy rule}

Usually, monetary policy is considered to follow the 'Taylor rule,' which postulates that the interest rate gets adjusted by the central bank according to deviations of the inflation rate (of all goods and services) and of the output level from their target values. In our model, goods prices are constant (or absent); only real-estate prices fluctuate. Within the narrow boundaries of our model, we will ask whether the central bank should take asset-price inflation into account by designing monetary policy. Traditionally, the reluctance of the US central bank to react to asset-price volatility had been enshrined in the socalled 'Greenspan doctrine,' which argues in favor of an 'indirect' approach for monetary policy (for an extensive analysis and discussion, see Campbell 2008). According to this indirect approach, monetary policy should support the 'natural' mean reverting tendencies of asset prices in the long run, without 'popping up' the bubbles directly. In our view such an 'indirect' approach ignores that, since the early 1980s' business cycles in the US seem to have changed from a 'Goodwin/Kalecki' type of growth cycle, where central banks combatted escalating wage and price inflation by weakening the bargaining power of workers via unemployment, to a pattern of leverage cycles driven by and interacting with asset-price fluctuations.

If the central bank in our model takes into account mortgage credit growth, $B^{\prime}(t) / B(t)$, compatible with a certain nominal income growth target (which in our stationary economy is zero), the monetary policy rule (22) might be as follows: $d(t)$ is the actual fund rate, $\rho$ is the 'natural' mortgage interest rate, and $0 \leq \kappa \leq 1$ are the weights for the mortgage credit-growth target versus the aggregate output gap. Equation (23) shows that the integration of the credit-growth variable into the monetary policy rule implies that deviations of the house-price level from the long-term supply price and the state of the housing market are both taken into account implicitly.

$$
\begin{aligned}
d(t) & =\frac{\rho}{\Psi}+\sigma\left(\kappa \frac{B^{\prime}(t)}{B(t)}+(1-\kappa)(y(t)-1)\right) \quad \Psi>1, \sigma>0 ; 0 \leq \kappa \leq 1 \\
\frac{B^{\prime}(t)}{B(t)} & =\frac{p^{\prime}(t)}{p(t)}+\frac{q^{\prime}(t)}{q(t)}
\end{aligned}
$$




$$
\begin{aligned}
r(t) & =\rho+s\left(d(t)-\frac{\rho}{\Psi}\right) & & 0<s<1 \\
\frac{n^{\prime}(t)}{n(t)} & =\vartheta\left(\frac{r(t)}{\rho}\right)^{u} \frac{(r(t)-n(t))}{n(t)} & & 0<\vartheta, u \geq 0
\end{aligned}
$$

The central bank sets the fund rate, $d(t)$, to influence the target mortgage rate, $r(t)$, according to (22). The target mortgage rate, $r(t)$, is linked to the fund rate, $d(t)$, via (24), which means (i) that in the stationary state the mortgage rate is a multiple of the fund rate, and (ii) that the mortgage rate reacts less than proportionallly to variations of the fund rate $(0<s<1)$. The actual mortgage rates, $n(t)$, adjust gradually according to equation (25) to the target mortgage rate. The speed of adjustment, $\vartheta$, might also depend on the ratio of the target rate to the 'natural' rate - the lower the target rate, $r(t)$, relative to the natural rate, $\rho$, the lower might be the speed of adjustment due to interest rigidity.

\section{4 'STYLIZED FACTS’ VERSUS 'DYNAMIC SIMULATIONS' OF THE MODEL}

We will try to 'mimic' some 'stylized facts' of house-price cycles in the US with our model. And we will ask whether reasonable monetary and fiscal policy rules could be identified to support stability.

In Figure 1, three house-price booms and busts can be identified between 1975 and 2012. The first one from 1975 to 1984 , the second one from 1984 to 1997 , and the third one from 1997 to 2012 (measured as the distance of the lower turning points). From 2012 to 2018, real houseprices increased by approximately 33 percent, indicating a new cycle. To avoid too much 'cluttering' in the empirical scatter plots, let us focus on the last two houseprice cycles since $1984 .^{10}$

In Figure 2a, a long-term upward shift of real house prices can be seen. Such a shift can be (partially) explained by 'real' factors such as urbanization, zoning restrictions, increasing scarcity of land in urban areas, lower rates of productivity growth in construction relative to other industries, quality changes, the growing relevance of pension funds in the search for inflation-protected assets, etc. 'Real' factors, however, tell only part of the story.

Figures $2 \mathrm{a}$ and $2 \mathrm{~b}$ show the - counter-clockwise - trajectories of real house prices relative to the GDP gap, empirically and simulated by our model. Starting from a specific 'stability scenario' (the detailed list of the parameter values is given in Appendix 1), a temporary downward mortgage interest shock (caused by 'overconfidence' with respect to the virtues of 'securitization') induces a huge boom followed by a severe contraction, then converges slowly back to equilibrium.

In Figures $3 \mathrm{a}$ and $3 \mathrm{~b}$ the corresponding counter-clockwise trajectories of the ratio of household debt to GDP relative to the GDP gap can be seen. Figures $4 \mathrm{a}$ and $4 \mathrm{~b}$ show the trajectory of the 'real' mortgage interest rate - defined from the viewpoint of a homeowner, as the difference between the 30-year fixed mortgage rate and the inflation rate of house prices. What we can see in Figure $4 \mathrm{a}$ are counter-clockwise cycles, marching into the negative territory during the bubble years from 2003 to 2005 .

Our model predicts a counter-clockwise trajectory of the debt-service ratio, which starts 2 percentage points below the 'natural' rate (Figure 5b). Empirically the debt-service burden (Figure 5a) varies also in a counter-clockwise way within much narrower bounds

10. All data retrieved from FRED (the Federal Reserve Bank of St. Louis), URL: https://fred. stlouisfed.org. Transformations and graphical presentations by the author using EVIEWS 9. 


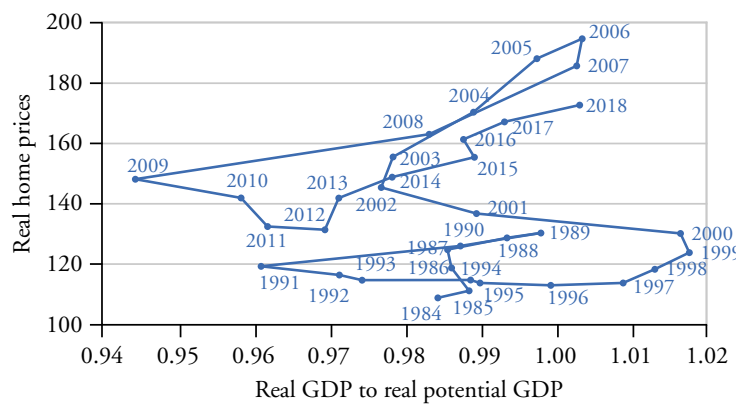

(a) The real houseprice cycle (1984-2018)

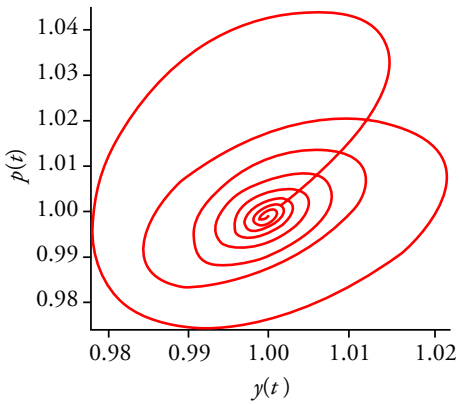

(b) Houseprices versus GDP

Figure 2 Real house prices and the GDP gap

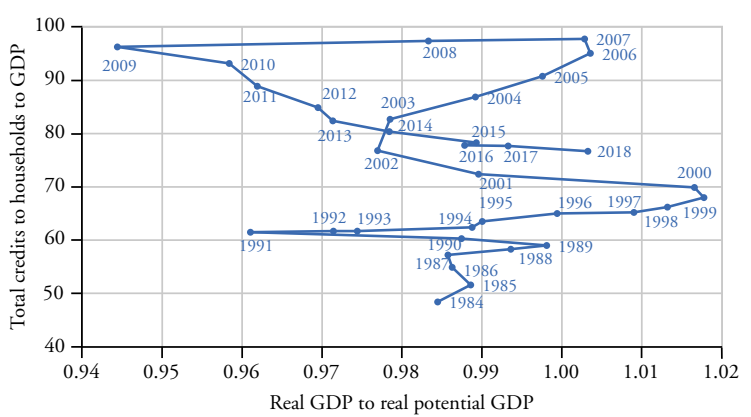

(a) The household debt cycle

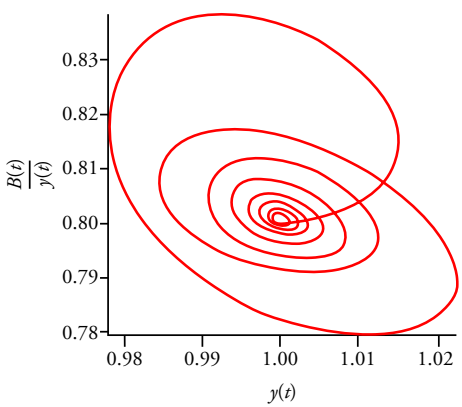

(b) Household debt to GDP versus GDP

Figure 3 Household-debt-to-GDP ratio and the GDP gap

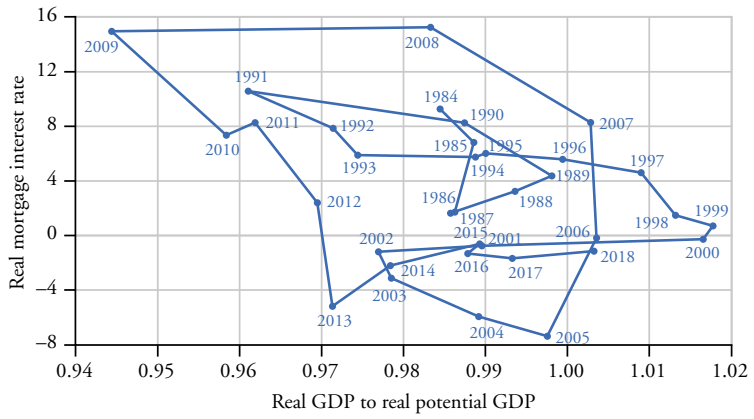

(a) Real mortgage interest rate and GDP gap

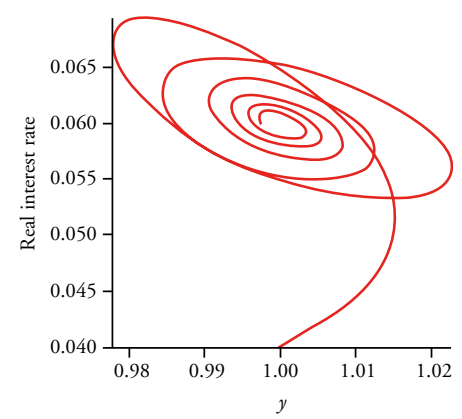

(b) Real interest rate and GDP

Figure 4 Real mortgage interest rate and the GDP gap 


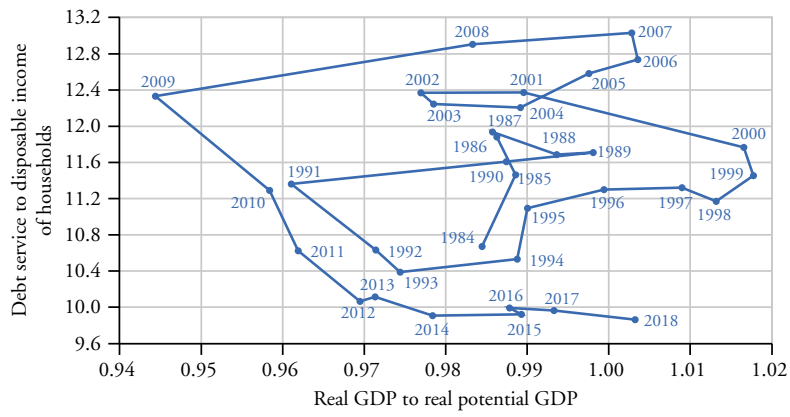

(a) Debt service to disposable income of households

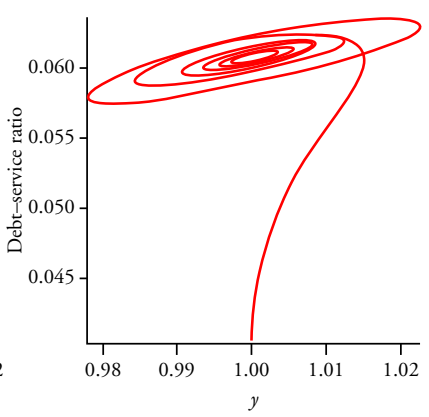

(b) The debt-service ratio versus GDP

Figure 5 Debt-service ratio and the GDP gap

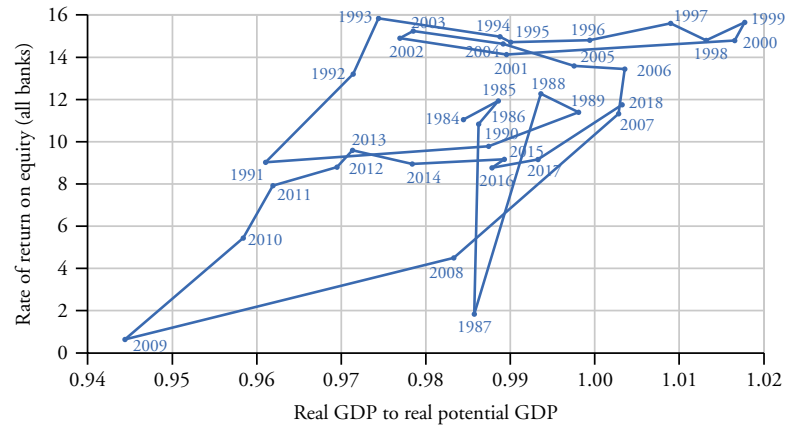

(a) Rate of return on equity

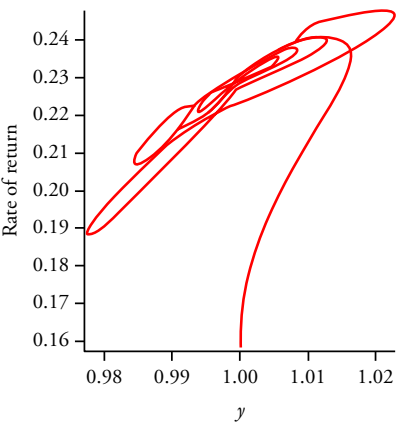

(b) Rate of return on equity

Figure 6 Rate of return on equity and the GDP gap

than the debt-to-GDP ratio. The debt-service ratio seems to be the decisive factor in limiting affordable credits - as our model postulates.

From 2007 to 2018 the period of extremely low interest rates and the ongoing restructuring of household debt (via conversion and bankruptcies of households) induced a reduction of the debt-service ratio to its lowest value in many years - in spite of the fact that the ratio of household debt to GDP is still, by historical standards, comparatively high (80 percent) and relative to disposable income even above 100 percent.

The rate of return on equity for all banks rises during the boom and falls during the recession (Figure 6a). Our model shows a similar movement (Figure 6b), predicting during the boom (the crisis) a counter-clockwise (clockwise) movement of the rate of return.

Figure 7 shows the trajectories of consumption expenditures and Figure 8 the personal saving rates of households. Our simulation generates three predictions: (i) Consumption (the saving rate) increases (decreases) with the degree of capacity utilization in the economy. (ii) At any particular value of the GDP gap, the average propensity to consume (the saving rate) is higher (lower) during the upswing and lower (higher) during the 'deleveraging' process. (iii) The consumption cycle (the saving cycle) will behave in a clockwise 

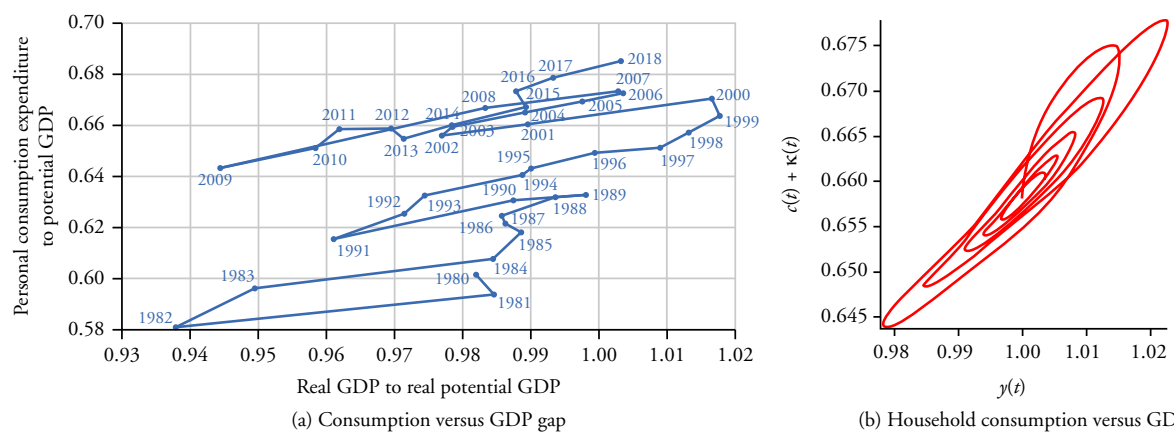

(b) Household consumption versus GDP

Figure 7 Household consumption and the GDP gap

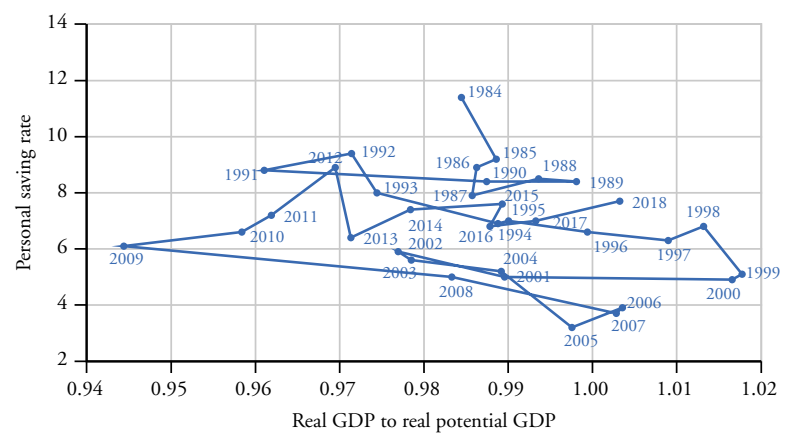

(a) Personal saving rate and GDP gap

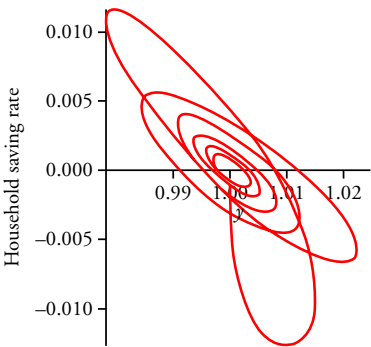

(b) Household saving rate and GDP

Figure 8 Household saving rate and the GDP gap

(counter-clockwise) manner. While the first prediction holds, the second and third predictions can be 'verified' at best partially: there seem to be two consumption and saving cycles separated by a structural break in the period 1997-2000, as the share of consumption to potential GDP drifted upwards (and the saving rate downwards), a process probably related to the overlapping real-estate and stock-exchange bubbles of the late $1990 \mathrm{~s} .{ }^{11}$ During the long period from 1992 to 2005 investment in real estate seemed to offer a route for the 'effortless' creation of 'virtual' net wealth - creating incentives for households to reduce the saving rates (see Figure 8a) dramatically, from nearly 10 percent to 3 percent of personal income. ${ }^{12}$

11. In our model the initial value of the saving rate is slightly negative, as the sudden decrease of the interest rate lowers the saving rates of creditors by more than it raises the saving rate of debtor households. The reason is that the creditor households suffer also from lower interest on government securities. 12. From a Keynesian perspective and given the rise in income inequality, this downward shift of the saving rate seems to be a puzzle, as 'redistribution from the poor to the rich' should increase the saving rate. Maybe the middle class tries desparately to 'keep up with the (richer) Joneses' via 'competitive conspicuous consumption,' even by going into debt. 


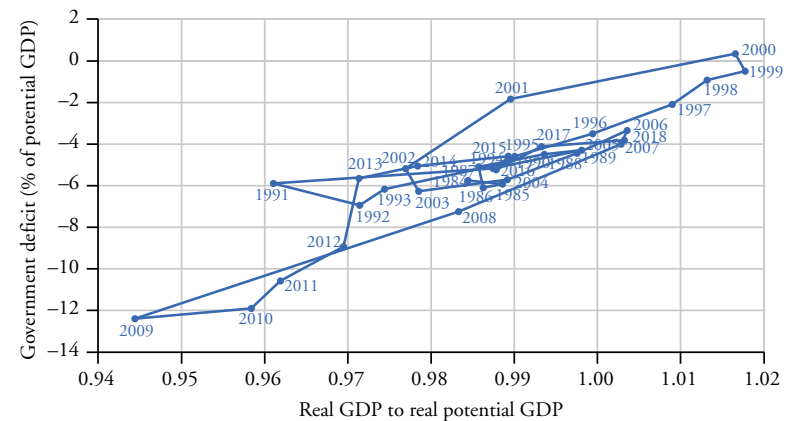

(a) Government deficit versus GDP gap

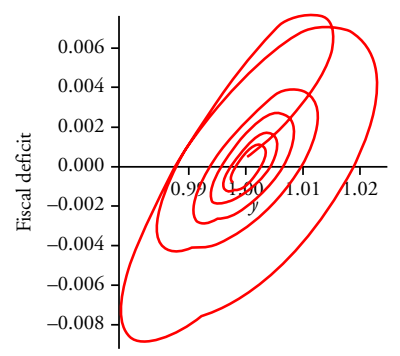

(b) The fiscal deficit versus GDP gap

Figure 9 Government fiscal balance and the GDP gap

Finally, let us take a look of the trajectories of the fiscal deficit as a percentage of potential GDP (Figures 9a and 9b). We have noted above that monetary policy had been expansionary between 2001 and 2003 to prevent a recession. It is interesting to note that between 2001 and 2003 fiscal policy had also been expansionary.

Let us summarize our 'stylized facts': Counter-clockwise trajectories of real house prices, of household debt, of the real interest rate, and of the debt-service ratio together with falling (rising) household saving rates in the boom (in the slump) reveal a typical pattern of credit cycles linked to the price volatility and the 'virtual' wealth effects in the 'realestate' market.

\section{SOME POLICY EXPERIMENTS}

\subsection{Monetary policy rules}

There are multiple ways in which credit cycles can get out of control. One way is to 'flatten' the monetary policy reaction curve, that is, to lower the parameter $\sigma$ in equation (22) sufficiently: Figure 10a shows the cycle at the abyss of instability. Higher volatility of house prices and output are the unavoidable result of a monetary policy reacting too 'doveishly.' Somewhat surprisingly, our first experiment seems to support the 'Greenspan-doctrine': Increasing the weight of $B^{\prime}(t) / B(t)$ in the rule function by setting $\kappa=1.0$ instead of $\kappa=0.5$ in (22) raises price and output volatility (Figure 10b). Focusing instead on the output gap (by setting $\kappa=0$ ) brings stability back again (Figure 11a). The intuition behind this peculiar result is that due to the counter-clockwise house-price and debt cycles, the growth rate of mortgage credit can still be positive (negative) as long as prices rise (fall) faster than the output falls (rises). Interest policy might therefore react somewhat too slowly to stabilize the system.

The following result (Figure 11b) seems to support our conjecture: if we increase $\sigma$, the speed of the federal fund rate reaction, both rules are now stabilizing. Nevertheless, the long-run overall performance of the GDP-gap rule with regard to output stability still seems to be superior, albeit at the expense of inducing higher price volatility.

There do exist many parameter changes, which make our system less stable: (i) lowering $s$ or $\vartheta$ or increasing $u$ in equations (24) and (25), that is, increasing interest rigidity relative to the fund rate; (ii) increasing $\nu$ or $\tau$, that is, raising the feasible level of household debt and/or the adjustment speed of the debt to the feasible level - a deliberate 


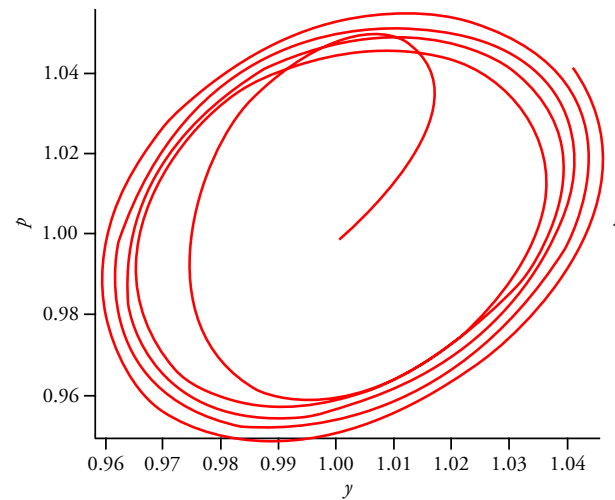

(a) Destabilizing monetary policy $(\sigma=0.25, \kappa=0.5)$

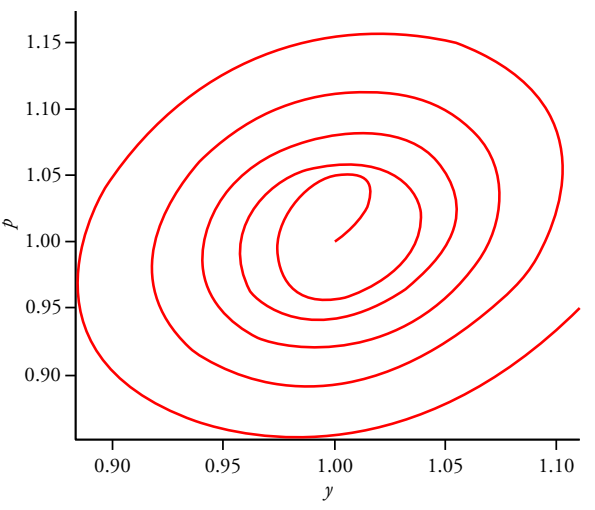

(b) Monetary policy rule focusing on credit growth $(\sigma=0.25, \chi=1)$

\section{Figure 10 Destabilizing monetary policy}

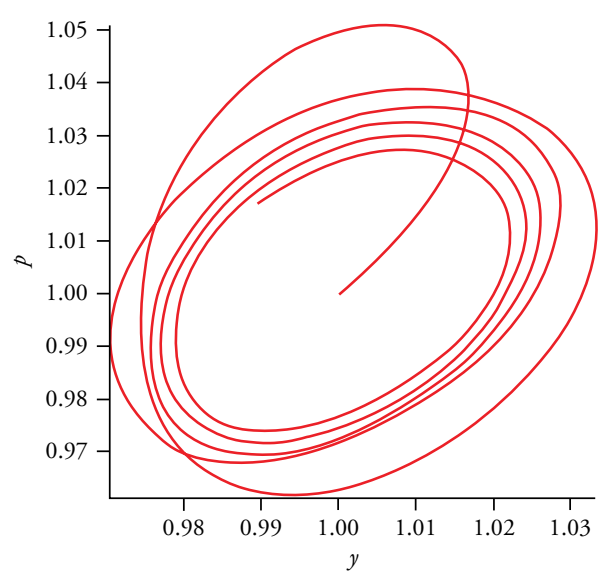

(a) $\sigma=0.25, \kappa=0$

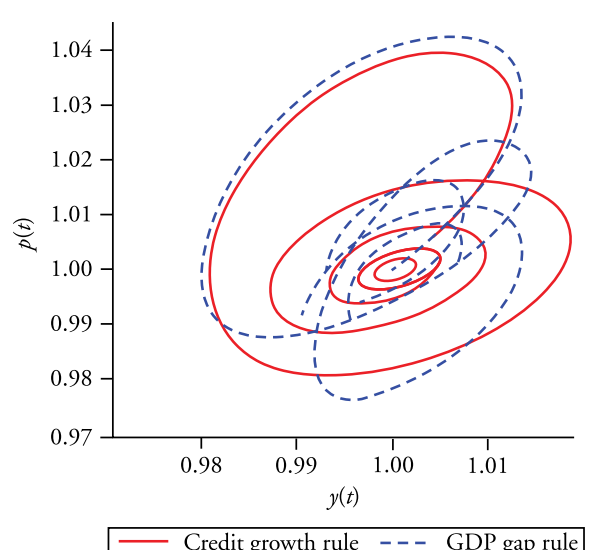

(b) GDP gap rule versus credit growth rule $(\sigma=0.75)$

Figure 11 Stabilizing monetary policy and the 'Greenspan-doctrine'

consequence of the Fannie Mae and Freddie Mac mortgage program supported by the government; (iii) a higher steady-state level of government debt; (iv) strengthening the 'Minsky' effect of endogenous risk attitudes in equation (13) by raising $\zeta$ (Figure 12b); (v) lowering the corporate or income-tax rate (Figure 12a); and (vi) shifting the burden of capital losses from creditor to debtor households (Figure 13a) by increasing the parameter $\omega$ in equations (5) and (6).

On the other hand, raising the steady-state equity ratio to mortgage credits, $\chi$, and/or increasing the speed of adjustment equity, $\eta$, to the desired level, $\chi B(t)$, reduces output volatility: financial regulation matters (Figure $13 \mathrm{~b}$ ). While stability increases, the equilibrium rate of return on equity declines in our model. As the banking sector must remain competitive with other sectors, the 'natural rate of interest,' $\rho$, could rise, depending upon 


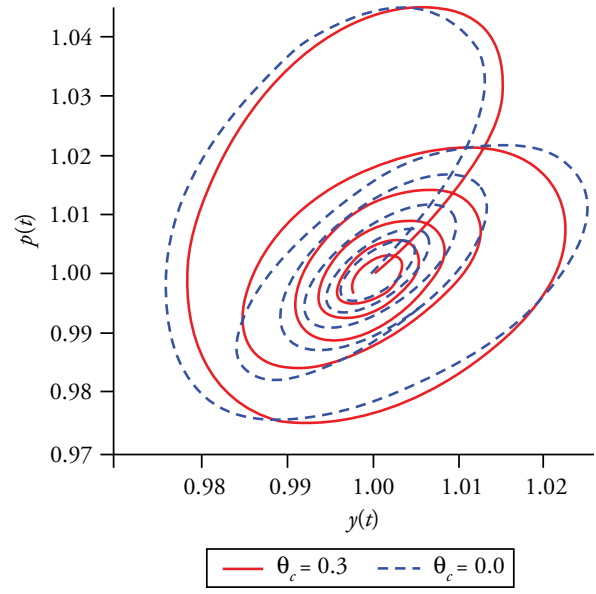

(a) Lowering corporate taxes

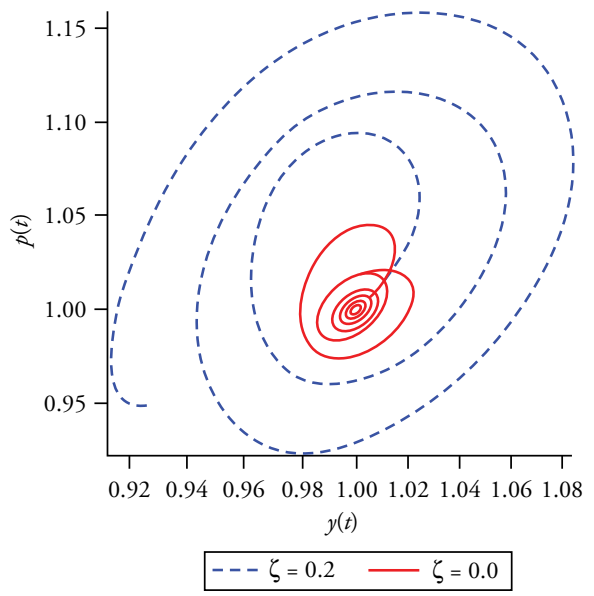

(b) The Minsky effect

Figure 12 Some destabilizing parameter changes

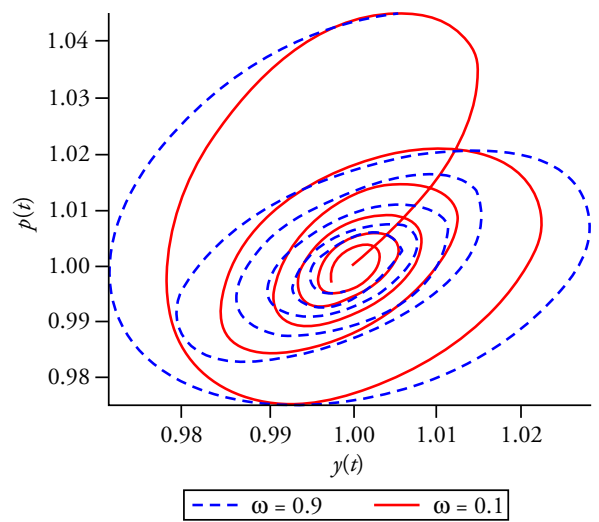

(a) Shifting the burden of capital losses to households

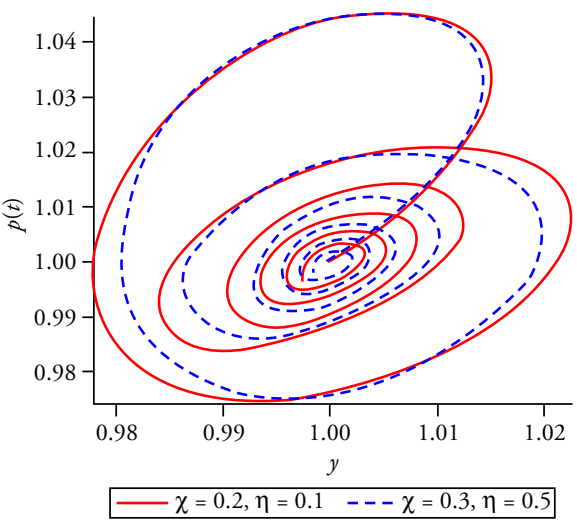

(b) Raising minimum equity and the adjustment speed

\section{Figure 13 Financial regulation matters}

the changing balance of risk and return. The structure of the banking sector will probably also change with higher $\chi$, as the degree of monopoly rises (market entry becomes more difficult).

\subsection{Fiscal policy rules}

The 'stability scenario' in our model includes a simple, moderate Keynesian policy rule (equation (21)), with parameters $\varphi=0.3, f=0.3$, and $j=1.0$. Let us switch to a somewhat more radical Keynesian policy by setting $f=1.0$. Figure 14 a shows the stabilizing effect of this rule. In our next experiment, we compare the radical Keynesian policy with a 


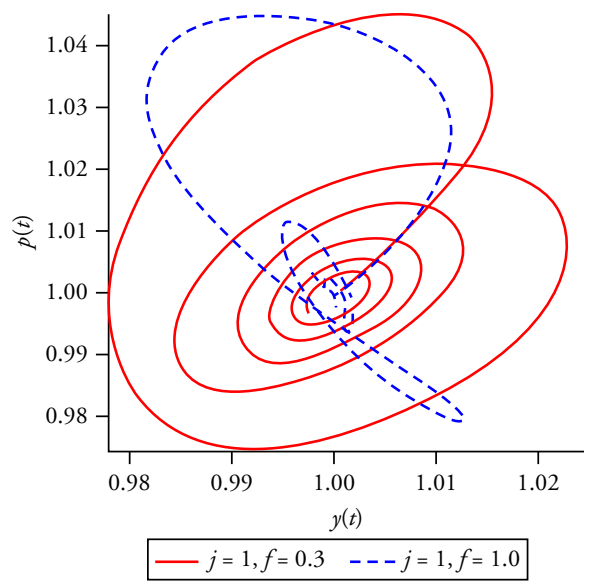

(a) 'Moderate' versus 'radical' Keynesian fiscal policy

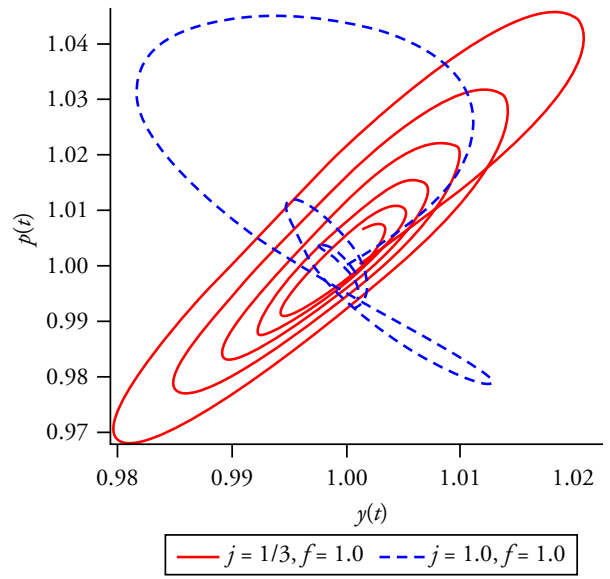

(b) 'Moderate' orthodox fiscal policy versus 'radical' Keynesian fiscal policy

Figure 14 Keynesian versus orthodox fiscal policy

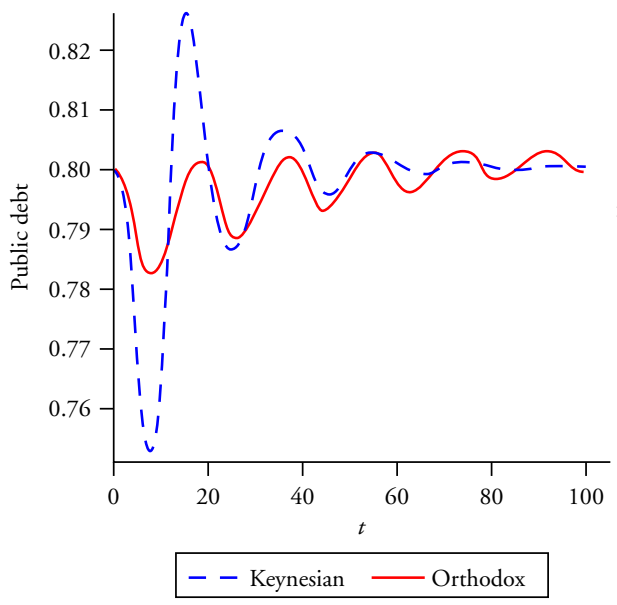

(a) 'Moderate' orthodox fiscal policy versus 'radical' Keynesian fiscal policy

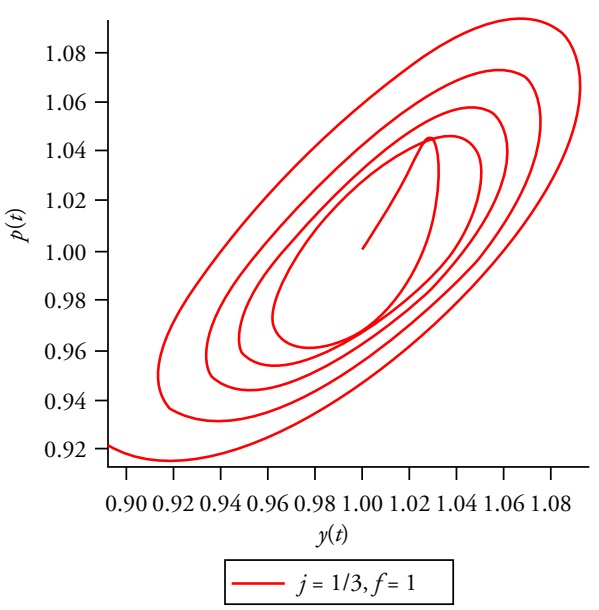

(b) The 'Maastricht' rule

Figure 15 Orthodox fiscal policy and instability

'moderate' orthodox policy by lowering the parameter $j$ to $j=1 / 3$, implying that fighting the budget deficit has higher priority. Figure $14 \mathrm{~b}$ shows again the superiority of the radical Keynesian policy with respect to output and price volatility. Of course, one might ask whether the Keynesian policy does change the behavior of the financial sector, either via endogenous risk attitudes or by some other mechanism (see, for instance, Kapeller et al. 2018). Obviously, our model does not take into account such strategic interactions.

In Figure 15a we see that the moderate orthodox policy reduces the variance of government debt (at the cost of higher output volatility). 
An orthodox approach, which is even worse than focusing on stabilizing the deficit, is the 'Maastricht' rule of stabilizing the debt-to-GDP ratio (equation (21)): an escalating cycle results (Figure 15b).

\section{SUMMARY AND CONCLUSIONS}

We tried to mimic some 'stylized facts' of real-estate cycles in the US with the help of a dynamic, non-linear post-Keynesian model. The model shows the interaction between a banking sector, a government sector and a household sector (with debtor and creditor households). The model shows the effects of a (downward) interest shock. Empirical versus theoretically predicted trajectories of house prices, household debt to GDP, and the debt-service burden, the real interest rate for homeowners, consumption and saving of households, the rate of return of the financial sector, and some other variables are compared. An important mechanism triggering instability are capital gains and losses, generating endogenous 'virtual' income and credit constraints. Our main conclusion is that vigorous (and symmetric) Keynesian monetary and fiscal policies complemented by financial regulation (higher minimum equity) are necessary to prevent 'virtual wealth' cycles from escalating. It is shown that an interest policy, which tries to control private credit growth, is somewhat inferior to an approach focusing on the GDP gap. If monetary policy is reacting 'hawkishly' enough, this difference becomes less important. We also show that fiscal rules like the 'Maastricht' rule or the rule of the 'Swabian housewife' have destabilizing consequences.

The elder proprietary middle class, anxiously looking forward to retirement, puts the government (and the government of the central bank) under permanent pressure to appreciate the value of their assets, as the meagre social security pensions in the US do not offer the slightest chance of maintaining the living standard during retirement (for a critical assessment see Laski/Walther 2015). One cannot understand the laissez-faire attitude of monetary authorities with regard to the 'irrational exuberance' and the financial follies during the asset-price bubbles of the past decades without taking these illusionary aspirations of the middle class into account. Furthermore, due to the shared economic interests with regard to the appreciation of asset prices, since the early 1980s the middle class became a convenient strategical ally of the 'one percent' - contrary to the period before. The policies implemented by this coalition are an opportunistic mixture of 'neoliberal' measures (with regard to labour laws, taxation, etc.) and anti-competitive measures to protect overvalued assets (for example, via zoning restrictions or the deliberate weakening of antitrust policies).

\section{REFERENCES}

Admati, A., Hellwig, M. (2013): The Banker's New Clothes: What's Wrong with Banking and What to Do About It, Princeton, NJ: Princeton University Press.

Bhaduri, A. (2011): A contribution to the theory of financial fragility and crisis, in: Cambridge Journal of Economics, 35(6), 995-1014.

Bhaduri, A., Laski, K., Riese, M. (2006): A model of interaction between the virtual and the real economy, in: Metroeconomica, 57, 412-427.

Blanchard, O.J. (1979): Speculative bubbles, crashes, and rational expectations, in: Economic Letters, 3, 387-389.

Campbell, J.Y. (2008): Asset Prices and Monetary Policy, Chicago: University of Chicago Press. 
Dejuán, Ó., Dejuán-Bitriá, D. (2018): A predator-prey model to explain cycles in credit-led economies, in: Review of Keynesian Economics, 6(2), 159-179.

DeLong, J.B., Shleifer, A., Summers, L.H., Waldmann, R.J. (1990): Positive feedback investment strategies and destabilizing rational speculation, in: Journal of Finance, 45, 379-395.

ECB (European Central Bank) (2010): Carry trades and exchange rates, in: Monthly Bulletin, March, 93-95.

Fama, E.F. (2014): Two pillars of asset pricing, in: American Economic Review, 104, 1467-1485.

Garriga, C., Hedlund, A. (2017): Mortgage debt, consumption, and illiquid housing markets in the Great Recession, Federal Bank of St. Louis, Working Paper, URL: https://doi.org/10.20955/ wp.2017.030.

Geneakopolous, J. (2010): The leverage cycle, in: NBER Macroeconomics Annual 2009, vol. 24, 1-65.

Godley, W. (2001): The developing recession in the United States, in: Banca Nationale del Lavoro, 54(219), 417-425.

Godley, W. (2002): The case for a severe recession, in: Challenge, 45(2), 27-51.

Godley, W., Lavoie, M. (2006): Monetary Economics: An Integrated Approach to Credit, Money and Income, New York: Palgrave.

Greenspan, A. (2003): Conference on 'Bank Structure and Competition,' Chicago, 8 May.

Hein, E. (2012): The Macroeconomics of Finance-Dominated Capitalism - and its Critics, Cheltenham, UK and Northampton, MA: Edward Elgar Publishing.

Hicks, J.R. (1950): A Contribution to the Theory of the Trade Cycle, Oxford: Oxford University Press.

Kalecki, M. (1943): Political aspects of full employment, in: The Political Quarterly, 14(4), 322-330.

Kapeller, J., Landesmann, M.A., Mohr, F.X., Schütz, B. (2018): Government policies and financial crises: mitigation, postponement or prevention?, in: Cambridge Journal of Economics, 42(2), 309-330.

Kindleberger, C.P. (1978): Manias, Panics, and Crashes: A History of Financial Crises, London: Palgrave Macmillan.

Koo, R.C. (2011): The world in balance sheet recession: causes, cures and politics, in: Real-World Economics Review, 58(12), 19-37.

Łaski K., Walther, H. (2015): Kalecki's profits equation after 80 years, in: Toporowski, J., Mamica, Ł. (eds), Michat Kalecki in the 21st Century, Palgrave Studies in the History of Economic Thought Series, London: Palgrave Macmillan, 131-156.

Mackay, C. (1841): Extraordinary Popular Delusions and the Madness of Crowds, London: Richard Bentley.

Minsky, H.P. (1992): The financial instability hypothesis, Working Paper No 74, The Jerome Levy Institute of Bard College, New York. (Reprinted in Arestis, P., Sawyer, M. (eds) (1994): Handbook of Radical Political Economy, Aldershot, UK and Brookfield, VT: Edgar Elgar Publishing, 148-157.)

Palley, T. (1994): Debt, aggregate demand and the business cycle: an analysis in the spirit of Kaldor and Minsky, in: Journal of Post Keynesian Economics, 16, 371-390.

Palley, T. (2011): A theory of Minsky super-cycles and financial crises, in: Contributions to Political Economy, 30, 31-46.

Piazzesi, M., Schneider, M. (2016): Housing and macroeconomics, URL: https://web.stanford.edu/ - piazzesi/housingandmacroeconomics.pdf.

Ryoo, S. (2013): Minsky cycles in Keynesian models of growth and distribution, in: Review of Keynesian Economics, 1(1), 37-70.

Samuelson, P.A. (1939): Interactions between the multiplier analysis and the principle of acceleration, in: Review of Economic Statistics, 21, 75-78.

Scheinkman, J., Wei, X. (2003): Overconfidence and speculative bubbles, in: Journal of Political Economy, 111, 1183-1219.

Shiller, R. (2000): Irrational Exuberance, Princeton, NJ: Princeton University Press.

Werner, R.A. (2015): The quantity theory of credit, in: Rochon, L.-P., Rossi, S. (eds), The Encyclopedia of Central Banking, Cheltenham, UK and Northampton, MA: Edward Elgar Publishing, 416-418. 
402 European Journal of Economics and Economic Policies: Intervention, Vol. 16 No. 3

\section{APPENDIX 1}

The parameter list of the 'stability scenario' (the executable Maple 15 file is available on request from the author):

$\alpha=0.01, \quad \beta=5.0, \quad \rho=0.06, j=1.0, \eta=0.1, \quad b_{d}=0.9, \quad b_{c}=0.4, \quad \mu_{d}=0.9$, $\mu_{\mathrm{\kappa}}=0.3, \theta_{w}=0.3, \nu=0.08, \omega=0.1, \xi=0, \varphi=0.3, \sigma=0.5, \Psi=0.3, \varepsilon=0.8$, $f=0.3, \quad \tau=0.009, \theta_{c}=0.3, \quad \chi=0.2, \quad l=0.02, \quad \chi=0.5, \quad \Omega=0.5, \quad T=0.02$, $\delta=0.02, \theta_{p}=0.02, \vartheta=0.06, \epsilon=\frac{\nu(1+T)}{\rho+\theta_{p}+\delta}, P_{o}=\frac{\left(1-\theta_{w}\right)\left(1-\theta_{c}\right)\left(\rho(\epsilon+\Omega \varepsilon)-\frac{\rho}{\Psi} l((1-\chi) \epsilon+\varepsilon)-T\right)}{\chi \epsilon}$, $s=0.6$. 